Pilots Club, Sussex Sportsmens Association, and the Inner Wheel Clubs of Brighton and East Brighton.

\author{
References \\ 1 Colling, A, et al, British Medical fournal, 1976, 2, 1169. \\ 2 Kannel, W B, et al, Circulation, 1975, 51, 606. \\ ${ }^{3}$ Pantridge, J F, and Geddes, J S, Lancet, 1967, 2, 271 \\ 4 White, N M, et al, British Medical fournal, 1973, 3, 618 \\ ${ }^{5}$ Briggs, R S, et al, British Medical fournal, 1976, 2, 1161.
}

Armstrong, A, et al, British Heart fournal, 1972, 34, 67.

7 Cobb, L A, et al, Circulation, 1975, 52, suppl No 3, p 223.

${ }^{8}$ Amey, B D, Harrison, E E, and Straub, E J, fournal of the American College of Emergency Physicians, 1976, 5, 429.

${ }_{9}$ Lund, I, and Skulberg, A, Lancet, 1976, $2,702$.

10 Bell, J A, and Hodgson, H J F, Brain, 1974, 97, 361.

11 Norris, J R, and Chandrasekar, S, Journal of Chronic Diseases, 1971, 24, 585.

12 Cobb, L A, personal communication.

${ }^{13}$ British Medical fournal, 1975, 2, 5.

\title{
Randomised trial of a mobile coronary care unit for emergency calls
}

\author{
J R HAMPTON, CHRISTINE NICHOLAS
}

British Medical fournal, 1978, 1, 1118-1121

\section{Summary and conclusions}

$A$ randomised trial was conducted to assess the value of sending a mobile coronary care unit (MCCU) to all emergency calls other than those for children or for patients injured in road-traffic accidents or brawls. Over 15 months 6223 calls for emergency ambulances were considered for the study, but a routine ambulance had to be dispatched on 2583 occasions because the MCCU was not available. A group of 1664 patients was randomly allocated to transport by the MCCU and 1676 patients to routine transport. In these groups the prehospital mortality among patients with heart attacks was $45 \%$ and $47 \%$, and no patient survived resuscitation attempts long enough to leave hospital. During the same period general practitioners sent 190 patients with heart attacks to hospital in routine ambulances and none of them died during the interval between the call for the ambulance and arrival at hospital.

Although it may be worth equipping all emergency ambulances with a defibrillator, MCCUs as at present envisaged will not appreciably affect mortality from heart attacks.

\section{Introduction}

Two studies of a mobile coronary care unit (MCCU) in Nottingham have shown that reduced mortality from heart attacks associated with its use almost certainly resulted from the inadvertent transport of low-risk patients ${ }^{1}$ and that adding a doctor to the specially trained ambulance crews did not improve patient survival. ${ }^{2}$ Patients with heart attacks who call for help from a general practitioner seem to have a low mortality rate, while a higher mortality rate is associated with emergency (999) calls $^{3}$; it is, however, extremely difficult for an ambulance controller to identify patients with heart attacks among the many emergency calls he receives. ${ }^{4}$ To assess the value of using an MCCU-type ambulance for all emergency calls we decided

Department of Medicine, General Hospital, Nottingham NG1 6HA J R HAMPTON, DM, FRCP, consultant physician and reader in medicine CHRISTINE NICHOLAS, BSC, research assistant to conduct a randomised trial of sending the MCCU or routine ambulance to emergencies for which an ambulance was summoned by a member of the public.

\section{Patients and methods}

The study was limited to the Nottingham conurbation. All local general practitioners were told that until further notice the use of the MCCU would be restricted to emergency (999) calls. Any emergency call reaching the Nottingham Ambulance Control Centre was considered by the ambulance controller for inclusion in the study. A routine ambulance was dispatched electively if the call concerned either a road-traffic accident, a brawl or other obvious trauma, or if the patient was a child; or if the MCCU was already busy or was too far away from the emergency to reach the patient within 10 minutes. The MCCU was dispatched electively if no routine ambulance could reach the patient within 10 minutes; if an emergency call was made by a general practitioner who specially requested that the MCCU should be sent; or if the ambulance controller was given information that made him believe it was unjustifiable to choose the type of ambulance at random.

For all other emergencies the controller opened the next in a sequence of envelopes that contained cards in random order indicating that either the MCCU or a routine ambulance should be dispatched. The ambulance controller indicated on his record sheet which sort of ambulance had been sent, and how it had been selected. The controllers' records were examined daily; all patients other than those known to be children or to have been concerned in road-traffic accidents or brawls were identified, and the accident and emergency department records of these patients were reviewed. Any patient who had not been admitted to hospital was considered to have had a "trivial illness" and was not followed up further. Clinical and laboratory data were collected for any patients admitted to hospital until their diagnosis was established, and for patients who were suspected of having had a heart attack until their discharge or death. In addition, admissions to the coronary care units and medical wards of both Nottingham General and City Hospitals were reviewed daily so that patients with heart attacks who had been sent in by routine ambulance by their general practitioner could be identified. Data from all such patients were collected until discharge or death.

Basic information about the patient's age and sex and the place where the illness occurred were collected for all patients; details of the history, physical signs, and laboratory data were collected for all patients who were suspected of having had heart attacks. After discharge these patients' records were reviewed, and the patients were assigned to one of the following subdivisions of "heart attack" (categories $(a)$ and $(b)$ approximately correspond to the WHO definition of definite myocardial infarction): (a) definite myocardial infarction-a convincing history with classical electrocardiogram (ECG) and sequential enzyme changes; $(b)$ probable infarction-a convincing history and either classical ECG or enzyme changes; $(c)$ possible infarction-convincing history with ECG abnormalities not 
characteristic of infarction and marginal enzyme changes; $(d)$ ischaemic heart disease-chest pain in patients with good evidence of previous infarction but no ECG or enzyme changes to suggest a recent infarction; $(e)$ chest pain of uncertain cause-patients admitted with chest pain for which no adequate diagnosis was made; $(f)$ prehospital death-patients found dead on arrival in hospital when a necropsy showed that death was due to myocardial infarction or coronary artery disease.

\section{Results and comment}

During the 15-month study 6223 emergency calls from members of the public were considered for randomisation for transport by the MCCU or a routine vehicle. On 2583 occasions the MCCU was either already busy or was too far away to be used, so a routine vehicle was dispatched electively. On the other 3340 occasions a randomising envelope was opened by the ambulance controller; the MCCU was dispatched to 1664 patients and a routine vehicle to 1676 . In addition the MCCU was dispatched electively in response to 335 emergency calls, either because no routine vehicle was near the patient or because there seemed to be some compelling emergency that made the use of a routine vehicle inappropriate. This group differed from the others, since on 25 occasions $(7 \%)$ the emergency call was made by a general practitioner rather than a member of the public.

Table I shows the final diagnoses of these 6258 patients. In the group to which the MCCU was sent electively there were 50 patients with heart attacks $(15 \%)$, presumably reflecting the special information given to the ambulance controllers. Among the remaining groups the proportion of patients with heart attacks was much smaller $(3 \cdot 2-4 \cdot 8 \%)$, and the difference between the two randomised groups just achieved significance $(0.05-\mathrm{P} \quad 0.02)$. In all groups the most common problems were "trivial illnesses" (table I), which included a wide variety of conditions; but in no case was the patient admitted to hospital, $46-57 \%$ of the patients in each group being sent home from the accident and emergency department. The next most common diagnosis was trauma. When the MCCU was dispatched electively 21 patients $(6 \%)$ were found to be injured, but in the other groups $15-18 \%$ of the patients had trauma that required hospital admission. There was a small proportion of calls $(2-5 \%)$ in which insufficient information was given to the ambulance controller to enable him to exclude calls for children or patients injured in road-traffic accidents (table I).

The groups of patients selected in different ways for transport by the MCCU or routine ambulances who were eventually diagnosed as having had a heart attack (table II) were similar in mean age $(60-62)$ and in the proportion of men (66-77\%). Table II and subsequent tables include data on patients with heart attacks for whom ambulances were called by a general practitioner so that a routine vehicle was sent electively. Out of 190 patients sent to hospital this way, $183(96 \%)$ were at home when the heart attack occurred, compared with 31 of the group randomly allocated to routine vehicles $(58 \%)$, and 57 of those randomly allocated to the MCCU $(71 \%)$. The differences between the last three groups were not significant. A relatively high proportion of patients $(80 \%)$ in the group to which the MCCU was sent electively were at home; half of these patients called a general practitioner rather than an emergency ambulance, and the MCCU was dispatched because of a specific request by the general practitioner.

The figure shows the intervals between the onset of symptoms and the call for the ambulance in the different groups of patients. Those randomly allocated to the MCCU or routine vehicles were similar, since about half the emergency calls had been made within 30 minutes. In the group of 190 patients who had called their general
TABLE II-Numbers of patients with heart attacks allocated either randomly or electively to transport by mobile coronary care unit (MCCU) or routine ambulances

\begin{tabular}{|c|c|c|c|c|c|}
\hline & \multicolumn{2}{|c|}{$\begin{array}{l}\text { Randomised } \\
\text { groups }\end{array}$} & \multicolumn{2}{|c|}{$\begin{array}{l}\text { Non-randomised } \\
\text { groups }\end{array}$} & \multirow{2}{*}{$\begin{array}{c}\text { Call by } \\
\text { GP for } \\
\text { routine } \\
\text { ambulances }\end{array}$} \\
\hline & MCCU & $\begin{array}{c}\text { Routine } \\
\text { ambulances }\end{array}$ & MCCU & \begin{tabular}{|c|} 
Routine \\
ambulances
\end{tabular} & \\
\hline 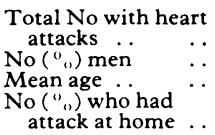 & $\begin{array}{l}80 \\
53(66) \\
62 \\
57(71)\end{array}$ & $\begin{array}{l}53 \\
41(77) \\
60 \\
31(58)\end{array}$ & $\begin{array}{l}50 \\
36(72) \\
61 \\
40(80)\end{array}$ & $\begin{array}{l}83 \\
61(73) \\
61 \\
47(56)\end{array}$ & $\begin{array}{l}190 \\
131(69) \\
62 \\
183(96)\end{array}$ \\
\hline
\end{tabular}

practitioner initially and who were therefore transported by routine vehicles the delay period was significantly $(P<0.001)$ greater, the ambulance having been called to half of them $3 \frac{1}{2}$ hours after the onset of symptoms. The 50 patients with heart attacks for whom an emergency call was made and to whom the MCCU was sent electively occupied an intermediate position, calls for the ambulance having been made for half of them by $2 \frac{1}{2}$ hours. The ambulance response times (the intervals between the telephone call and the arrival of the ambulance) also differed appreciably among the four groups for whom emergency calls had been made (an ambulance having reached the patient within 10 minutes on $87-94 \%$ of occasions in the different groups) and in the 190 patients for whom a routine ambulance was called by a general practitioner $(15 \%$ of patients being reached within 10 minutes).

Table III shows the prehospital and hospital mortality rates of the different groups. The proportion of prehospital deaths was similar

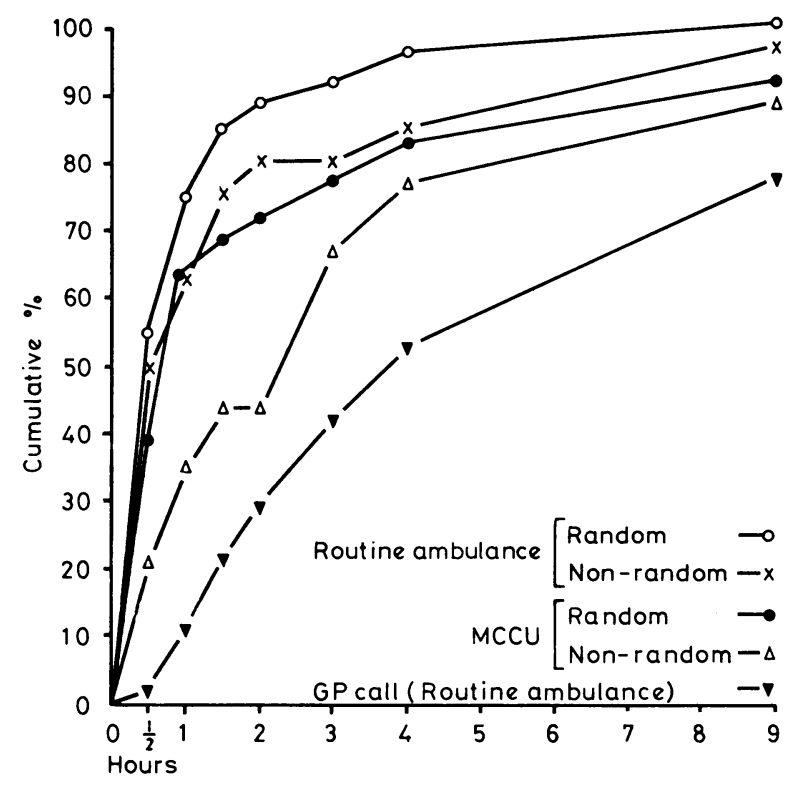

Intervals between onset of symptoms and call for ambulance in patients with heart attacks allocated either randomly or electively to transport by mobile coronary care unit (MCCU) or routine ambulances.

TABLE I-Final diagnoses in patients allocated either randomly or electively to transport by mobile coronary care unit (MCCU) or routine ambulances. Figures are numbers (" $\left.{ }^{\prime}\right)$ of patients

\begin{tabular}{|c|c|c|c|c|c|c|c|c|c|}
\hline & Diagnosis: & $\begin{array}{l}\text { Heart } \\
\text { attack }\end{array}$ & $\begin{array}{c}\text { Trivial } \\
\text { illnesses }\end{array}$ & Trauma & Medical & Surgical & $\begin{array}{l}\text { Children or } \\
\text { road-traffic } \\
\text { accident }\end{array}$ & $\begin{array}{c}\text { Dead } \\
\text { (not heart } \\
\text { attack) }\end{array}$ & Total \\
\hline \multicolumn{10}{|c|}{ Rundomised groups } \\
\hline$\underset{\text { Routine ambulance }}{\text { MCCU }}$ & $\begin{array}{l}\ldots \\
\ldots\end{array}$ & $\begin{array}{l}80(4 \cdot 8) \\
54(3 \cdot 2)\end{array}$ & $\begin{array}{l}883(53) \\
897(53)\end{array}$ & $\begin{array}{l}270(16) \\
256(15)\end{array}$ & $\begin{array}{l}229(14) \\
234(14)\end{array}$ & $\begin{array}{l}115(7) \\
132(8)\end{array}$ & $\begin{array}{l}42(2) \\
65(4)\end{array}$ & $\begin{array}{l}45(2) \\
38(2)\end{array}$ & $\begin{array}{l}1664 \\
1676\end{array}$ \\
\hline \multicolumn{10}{|c|}{ Non-randomised groups } \\
\hline $\begin{array}{l}\text { MCCU } \\
\text { Routine ambulance }\end{array}$ & $\ldots$ & $\begin{array}{l}50(15) \\
83(3 \cdot 3)\end{array}$ & $\begin{array}{r}156(46) \\
1476(57)\end{array}$ & $\begin{aligned} 21 & (6) \\
467 & (18)\end{aligned}$ & $\begin{array}{r}55(17) \\
285(11)\end{array}$ & $\begin{array}{r}25(7) \\
199(8)\end{array}$ & $\begin{array}{l}15(5) \\
17(0 \cdot 7)\end{array}$ & $\begin{array}{l}13(4) \\
56(2)\end{array}$ & $\begin{array}{r}335 \\
2583\end{array}$ \\
\hline
\end{tabular}


TABLE III-Mortality before arrival in hospital and after admission in patients with heart attacks allocated randomly or electively to transport by mobile coronary care unit $(M C C U)$ or routine ambulances

\begin{tabular}{|c|c|c|c|c|c|}
\hline & \multicolumn{2}{|c|}{$\begin{array}{c}\text { Randomised } \\
\text { groups }\end{array}$} & \multicolumn{2}{|c|}{$\begin{array}{l}\text { Non-randomised } \\
\text { groups }\end{array}$} & \multirow{2}{*}{$\begin{array}{c}\text { Call by } \\
\text { GP for } \\
\text { routine } \\
\text { ambulances }\end{array}$} \\
\hline & $\mathrm{MCCU}$ & $\begin{array}{c}\text { Routine } \\
\text { ambulances }\end{array}$ & MCCU & $\begin{array}{c}\text { Routine } \\
\text { ambulances }\end{array}$ & \\
\hline $\begin{array}{l}\text { No with heart } \\
\text { attacks . . } \\
\text { No (\%) dead before } \\
\text { arrival in hospital } \\
\text { No admitted to } \\
\text { hospital. } \\
\text { No who died in } \\
\text { hospital (" } \\
\text { admissions) } \\
\end{array}$ & $\begin{array}{l}80 \\
36(45) \\
44 \\
7(16)\end{array}$ & $\begin{array}{l}53 \\
25(47) \\
28 \\
8(28)\end{array}$ & $\begin{array}{l}50 \\
9(18) \\
41 \\
6(14)\end{array}$ & $\begin{array}{l}83 \\
35(42) \\
48 \\
10(21)\end{array}$ & $\begin{array}{l}190 \\
0 \\
190 \\
32(17)\end{array}$ \\
\hline $\begin{array}{l}\text { Total mortality } \\
\text { (") patients with } \\
\text { heart attacks) }\end{array}$ & $43(53)$ & $33(62)$ & $15(30)$ & $45(54)$ & $32(17)$ \\
\hline
\end{tabular}

TABLE IV-Effect of resuscitation attempts by ambulance crews on patients with heart attacks allocated randomly or electively to transport by mobile coronary care unit $(M C C U)$ or routine ambulances

\begin{tabular}{|c|c|c|c|c|c|}
\hline & \multicolumn{2}{|c|}{$\underset{\text { groups }}{\text { Randomised }}$} & \multicolumn{2}{|c|}{$\begin{array}{l}\text { Non-randomised } \\
\text { groups }\end{array}$} & \multirow{2}{*}{$\begin{array}{l}\text { Call by } \\
\text { GP for } \\
\text { routine } \\
\text { ambulances }\end{array}$} \\
\hline & MCCU & $\begin{array}{c}\text { Routine } \\
\text { ambulances }\end{array}$ & $\mathrm{MCCU}$ & $\begin{array}{c}\text { Routine } \\
\text { ambulances }\end{array}$ & \\
\hline $\begin{array}{l}\text { No with heart } \\
\text { attacks . . }\end{array}$ & 80 & 53 & 50 & 81 & 190 \\
\hline $\begin{array}{l}\text { resuscitation } \\
\text { attempted }\end{array}$ & $32(40)$ & $15(28)$ & $15(30)$ & $18(22)$ & $2(1)$ \\
\hline $\begin{array}{l}\text { No alive on arrival } \\
\text { in hospital }\end{array}$ & 2 & 2 & 1 & 2 & 2 \\
\hline $\begin{array}{l}\text { No alive at discharge } \\
\text { from hospital .. }\end{array}$ & 0 & 0 & 0 & 0 & 1 \\
\hline
\end{tabular}

$(42-47 \%)$ in patients randomly allocated to transport by the MCCU or routine vehicles and in those to whom a routine vehicle was sent electively because the MCCU was not available. It was much lower $(18 \%$ ) in the group to which the MCCU was sent electively, and there were no prehospital deaths among the 190 patients for whom an ambulance was called by a general practitioner on a non-emergency basis. Presumably when a general practitioner found a patient to be dead a hearse was summoned rather than an ambulance; there were no deaths in this group in the interval between the call for the ambulance and the patients' arrival in hospital.

It is difficult to make useful comparisons of the clinical state and hospital course of the patients in this study because relatively few in each ambulance group were admitted to hospital (table III). Nevertheless, similar proportions of patients in the different ambulance groups were eventually diagnosed as having had definite or probable myocardial infarctions $(57-67 \%)$, possible infarctions or ischaemic heart disease $(21-26 \%)$, or chest pain of uncertain cause $(7-12 \%)$. Similar proportions of patients in the different ambulance groups also had chest pain, breathlessness, clinical signs suggestive of heart failure, and anterior and inferior infarctions on the ECG. Digoxin and diuretics were used with similar frequency in the different groups. Few patients in each group died in hospital, and the difference between the groups randomly allocated to the MCCU and to a routine vehicle (mortality $16 \%$ and $28 \%$ respectively) was not significant.

Table IV shows the number of patients in each group in whom resuscitation (defined as the use of cardiac massage or the defibrillator) was attempted by the ambulance crew. Only one patient who was resuscitated survived to leave hospital, and he was in the group for which a routine ambulance had been called by a general practitioner

\section{Discussion}

The results of this study confirm our view that there is little point in sending an MCCU to bring to hospital a patient who has been seen by a general practitioner; even when general practitioners specifically asked for the MCCU and it was sent no lives were saved. On the other hand, sending an MCCU to all emergency calls other than those concerning road-traffic accidents and children achieved equally little. Less than $5^{\circ}$ of such emergency calls concerned patients with heart attacks, and nearly half of these patients were dead on arrival in hospital whatever sort of transport was used.

The proportion of patients with heart attacks was higher in the group randomly allocated to transport by the MCCU compared with the group randomly allocated to routine vehicles $\left(4 \cdot 8^{\circ}\right.$, compared with $3 \cdot 2^{\circ}{ }^{\circ}$, a difference which just achieved significance). Of the patients with heart attacks, more in the group randomly allocated to the MCCU were at home when the attack occurred $\left(71^{\circ}{ }_{0}\right.$ compared with $58^{\circ}{ }_{0}$ in the group randomly allocated to routine ambulances). These differences between the randomised group raised the possibility that the ambulance controllers did not always follow the randomising procedure strictly, so that the two groups may not have been quite comparable. Nevertheless, it seems unlikely that the controllers were trying to bias the results by sending the MCCU preferentially to patients who were at home, for $54^{\circ}, 0$ of the total calls in each of the randomised groups concerned patients at home. The similarity between the two groups in prehospital mortality rates $\left(45^{\circ}{ }_{0}\right.$ and $\left.47^{\circ}{ }_{0}\right)$, and the similar numbers of initially successful prehospital resuscitations (two patients in each group) suggest that the groups were comparable. The difference in hospital mortality $\left(16^{\circ}{ }_{0}\right.$ in the group randomised to the MCCU and $28^{\circ}{ }^{\circ}$ in the group randomly allocated to routine ambulances) was not significant because the numbers of patients were too small; there is no reason to suppose that any action by the crew of the MCCU, who were trained and equipped only for defibrillation, affected hospital mortality.

This study was discontinued partly because, with some justification, the ambulance controllers thought that the MCCU was being used inefficiently. They believed that they could identify the patients who might benefit from it accurately enough to make it unacceptable for them to use it according to the randomising procedure. Certainly, the proportion of patients with heart attacks was much higher in the group to whom the MCCU was sent electively, and fewer of these patients were dead on arrival in hospital. But there is no reason why such patients should have had a much lower prehospital mortality rate than those to whom the MCCU was sent on a random basis, unless the two groups of patients were initially different. The differences in the delay between the onset of symptoms and the call for the ambulance, and the presence of patients who had been attended by a general practitioner in the "elective" group showed that the groups were indeed different. While it is easy to see why the ambulance controllers believed they were achieving better results when they used their discretion rather than the randomisation procedure, the evidence does not support them.

These results show only too clearly the paradox of the MCCU. If a patient is known to have had a heart attack because he has been seen by a general practitioner the MCCU is not needed. Nevertheless, patients who might benefit from an MCCU cannot be identified among the mass of emergency ambulance calls, so a single MCCU cannot be used efficiently. The Joint Working Party of the Royal College of Physicians and the British Cardiac Society recommended" that the DHSS should establish MCCU services on a national basis, and that doctor-manned MCCUs should be set up wherever possible. They suggested that several thousand lives might be saved every year in Britain if this was done. The results of the present study and the two previous Nottingham trials ${ }^{12}$ suggest that the Joint Working Party was over-optimistic. While there is no doubt that MCCUs can save a few lives, it seems unlikely that the existing services can contribute effectively to reducing the community mortality rate from heart attacks. A change in public behaviour, with an increased awareness of the symptoms of heart attacks and a willingness to bypass their general practitioner and then to give adequate information to ambulance controllers so that an MCCU can be dispatched, might radically reduce community mortality from heart attacks. This has been achieved 
in some cities in the USA, ${ }^{6}$ but the general level of health consciousness and the public attitude to family medicine and emergency care are so different in the USA that it is far from clear that American experience is relevant to the United Kingdom.

The number of lives that MCCUs can be expected to save in the United Kingdom is therefore small, so establishing MCCU services on a wider basis must be considered in competition with other developments that may well seem less dramatic to the public. Until patients' behaviour patterns change, the only way the MCCU concept can usefully be extended in this country is probably by equipping every ambulance that deals with emergencies with a defibrillator and training the crew to use it. The capital cost would not be great, and relatively few lives could certainly be saved for a reasonable outlay, provided that the extra cost of more highly trained ambulance crews was not excessive. The increased cost of the crews would probably be unacceptable unless the different ambulance functions were more formally separated.' A few well-equipped ambulances, manned by specially trained crews, should be used in emergencies, while the "bus" functions of ambulances could be performed by simpler vehicles, manned by crews with only basic training. MCCUs should be developed only as part of a national move towards a "two-tier" ambulance service.

We gratefully acknowledge the skill and endeavour of the crews who manned the Nottingham MCCU during the five years in which this and the two earlier studies were conducted. We also thank the ambulance controllers for co-operating in this study, and the Nottingham physicians, surgeons, and general practitioners for allowing us to record data from patients in their care. The research aspects of this study were supported by a grant from the DHSS.

\section{References}

${ }^{1}$ Hampton, J R, British Medical fournal, 1976, 1, 201.

2 Hampton, J R, Dowling, M, and Nicholas, C, Lancet, 1977, 1, 526

${ }^{3}$ Hill, J D, and Hampton, J R, British Medical fournal, 1976, 2, 1035.

* Cameron, M, Wilkinson, F, and Hampton, J R, British Medical fournal, 1975, 1, 384.

5 Joint Working Party of the Royal College of Physicians and the British Cardiac Society, Fournal of the Royal College of Physicians of London, 1975, 10, 5.

${ }^{6}$ Cobb, L A, et al, Circulation, 1975, 52, suppl No 3, p 223.

${ }^{7}$ Howat, J G M, and Kontny, E L, British Medical fournal, 1977, 4, 1298.

(Accepted 17 March 1978)

\section{If I Had. .}

\section{Cataract}

\section{BRIAN HARCOURT}

British Medical fournal, 1978, 1, 1121-1122

In occasional idle moments I look into my Snellen chart and realise that I can now read unaided only the $6 / 6$ line, whereas it used to be the $6 / 5$ line. I am very aware of the difference, and so sometimes ponder on my likely reactions if real trouble came my way and the clarity of one or both of my crystalline lenses became impaired.

\section{Causes and symptoms}

Cataract, of course, is an emotive word, and most ophthalmic surgeons sensibly tend to avoid using it with patients, unless matters have reached a stage where surgical treatment is envisaged, or unless directly questioned. They prefer to use the more innocuous, yet entirely accurate, term "lens opacities." The causes of cataract are numerous (see table), but by far the commonest is aging, and these senile changes are more frequent in diabetic patients and occur in them at an earlier age.

When the lens opacities are not congenital or the result of external agencies such as irradiation or trauma, both eyes tend to be affected. Even in such circumstances, however, initially deteriorating vision may affect one eye only, and this asymmetry may persist for some years. The symptoms are principally

General Infirmary, Leeds 1

BRIAN HARCOURT, MB, FRCS, consultant ophthalmic surgeon painless progressive loss of distance visual acuity, for the optical requirements of reading vision are much less stringent. In particular, if the nucleus of the lens becomes sclerotic, there is often a change in refraction towards myopia as cataract develops, so that in the early stages the patient may even feel

Principal causes of cataract

\begin{tabular}{|c|c|c|c|c|}
\hline Congenital & . & & .. & $\begin{array}{l}\text { (a) Hereditary } \\
\text { (b) Acquired: } \\
\text { rubella }\end{array}$ \\
\hline Acquired . & $\cdots$ & .. & .. & $\begin{array}{l}\text { (a) Senile } \\
\text { (b) Secondary to ocular disorders: } \\
\text { degenerative myopia } \\
\text { uveitis } \\
\text { retinal detachment } \\
\text { retinitis pigmentosa } \\
\text { (c) Metabolic: } \\
\text { diabetes } \\
\text { galactosaemia } \\
\text { homocystinuria } \\
\text { (d) Traumatic } \\
\text { (e) Irradiation: } \\
\text { infrared: . . glassblowers' cataract } \\
\quad x \text {-rays and gamma rays }\end{array}$ \\
\hline
\end{tabular}

temporarily advantaged by being able to read without spectacles.

The same specific comments are heard from patients repeatedly: they have difficulty in recognising acquaintances in the street, which may cause social embarrassment; they fail to read bus numbers and traffic signs clearly; loss of confidence when driving is common, especially in older patients, and this is partly the result of the other main symptom of cataract- 